\title{
Corticosteroid receptors involved in stress regulation in common carp, Cyprinus carpio
}

\author{
Ellen H Stolte ${ }^{1,2}$, Aurélia F de Mazon ${ }^{1,2,3}$, Karen M Leon-Koosterziel ${ }^{1,2,3}$, Maria Jęsiak ${ }^{1,2,3}$, Nic R Bury ${ }^{3}$, \\ Armin Sturm ${ }^{3}$, Huub F J Savelkoul ${ }^{2}$, B M Lidy Verburg van Kemenade ${ }^{2}$ and Gert Flik ${ }^{1}$ \\ ${ }^{1}$ Department of Animal Physiology, Radboud University, Toernooiveld 1, 6525 ED Nijmegen, The Netherlands \\ ${ }^{2}$ Cell Biology and Immunology Group, Wageningen University, Marijkeweg 40, 6709 PG Wageningen, The Netherlands \\ ${ }^{3}$ Department of Biochemistry, King's College London, Franklin-Wilkins Building, 150 Stamford Street, London SE1 9NH, UK \\ (Correspondence should be addressed to G Flik; Email: g.flik@science.ru.nl)
}

\begin{abstract}
In higher vertebrates, mineralo- (aldosterone) and glucocorticoids (cortisol/corticosterone) exert their multiple actions via specific transcription factors, glucocorticoid (GR) and mineralocorticoid (MR) receptors. Teleostean fishes lack aldosterone and mineral regulatory processes seem under dominant control by cortisol. Despite the absence of the classical mineralocorticoid aldosterone, teleostean fishes do have an MR with cortisol and possibly 11-deoxycorticosterone (DOC) (as alternative for aldosterone) as predominant ligands. We studied corticoid receptors in common carp (Cyprinus carpio L). Through homology cloning and bioinformatic analysis, we found duplicated GR genes and a single MR gene. The GR genes likely result from a major genomic duplication event in the teleostean lineage; we propose that the gene for a second MR was lost.
\end{abstract}

Transactivation studies show that the carp GRs and MR have comparable affinity for cortisol; the MR has significantly higher sensitivity to DOC, and this favours a role for DOC as MR ligand in fish physiology. mRNA of the GRs and the $\mathrm{MR}$ is expressed in forebrain (in pallial areas homologous to mammalian hippocampus), corticotrophin-releasing hormone $(\mathrm{CRH})$ cells in the pre-optic nucleus (NPO) and pituitary pars distalis ACTH cells, three key neural/endocrine components of the stress axis. After exposure to prolonged and strong (not to mild acute) stressors, mRNA levels of both GRs and MR become down-regulated in the brain, but not in the NPO CRH cells or pituitary ACTH cells. Our data predicts a function in stress physiology for all CRs and suggest telencephalon as a first line cortisol target in stress.

Journal of Endocrinology (2008) 198, 403-417

\section{Introduction}

The adrenal cortex of mammals produces cortisol (or corticosterone) as glucocorticoid and aldosterone as mineralocorticoid. The function of these steroids is ultimately specified by the transcription factors (glucocorticoid and mineralocorticoid (MR) receptors) that mediate their actions in the diverse targets and that define which genes will be activated or repressed. Interrenal cells of teleostean fishes produce cortisol as the major steroid; in addition, deoxycorticosterone (DOC; a possible side product of progesterone conversion by 21-hydroxylase activity in cortisol pathway) is found in fish plasma (Sturm et al. 2005). Aldosterone is an evolutionary more recent steroid (Bridgham et al. 2006), believed to be absent in teleostean fishes (Balment \& Henderson 1987).

In all vertebrates, glucocorticosteroids play a key regulatory role in stress responses, growth and general metabolism, reproduction and immunity (Mommsen et al. 1999); and in terrestrial vertebrates, a specific subtask in mineral regulation is given to aldosterone. In fish, cortisol is intimately involved in the regulation of water and mineral balance (Gilmour 2005). At least two notions come to mind at the basis of a fundamentally different corticoid endocrinology in fishes: i) cortisol, the main corticosteroid exerts receptor-defined gluco- or mineralocorticoid actions and thus the regulation of water and mineral balance in fishes is not necessarily controlled by a mineralocorticoid and ii) the poorly studied DOC could, via a MR, act as a mineralocorticoid in fishes.

The corticoid receptors are promiscuous for ligands; cortisol is bound both by GR and MRs. The evolution of multiple corticosteroid receptors and their signalling pathways in vertebrates was extensively reviewed (Bridgham et al. 2006, Prunet et al. 2006, Baker et al. 2007, Bury \& Sturm 2007). An ancestral corticosteroid receptor (AncCR) is assumed to have been an effective receptor for cortisol; the AncCR may further have transmitted a DOC signal in the ancestors of fishes. Duplication of the AncCR gene led to separate GR and MR species over 450 million years ago; it is assumed that the MR retained an ancestral phenotype and that the GR lost sensitivity for aldosterone (Bridgham et al. 2006) in favour of cortisol. A second major genomic duplication event took 
place in teleostean fishes (not in tetrapods) and gave rise to further diversification of the corticosteroid receptor family. In the extant teleostean fishes studied so far, two different GR genes and one MR gene are found (Greenwood et al. 2003, Bury \& Sturm 2007). The interesting picture arises in fish in that a single ligand (cortisol) may steer three different receptors; therefore leading to diversification of receptors rather than of ligands.

Physiological research on the role of these fish receptors (combined) in stress and osmoregulation is as yet scarce. Although extensive research effort has been put in aspects of stress handling, smoltification and reproduction, and the effects of increased cortisol levels on GR expression (Maule \& Schreck 1991, Basu et al. 2003), only a few studies focussed on both GR and MR activities either simultaneously (Greenwood et al. 2003) or within the same species (Bury et al. 2003, Sturm et al. 2005). A role for MR activity in fish osmoregulation seems likely (Gilmour 2005, Sturm et al. 2005, Prunet et al. 2006), yet other MR functionality, for instance in brain function, or stress axis regulation requires far more research.

The endocrine stress axis is a pivotal and phylogenetically ancient regulatory system, key in adaptation of vertebrates to their dynamic environment (Wendelaar Bonga 1997) as well as in stress handling. The teleostean hypothalamic-pituitaryinterrenal (HPI) axis is comparable with the mammalian stress axis (Wendelaar Bonga 1997, Mommsen et al. 1999), a result of convergent evolution. Stressful sensory information is conveyed to the hypothalamic pre-optic area (NPO) and results in release of corticotrophin-releasing hormone $(\mathrm{CRH})$. NPO CRH cells in fish project directly to the rostral pars distalis adrenocorticotrophic hormone (ACTH)producing cells. ACTH released into the general circulation will then activate interrenal cells of the head kidney to produce and secrete cortisol. This cortisol will redistribute energy flows to deal with the stressor(s) and by doing so guarantees homeostasis (Wendelaar Bonga 1997).

In mammals, both GR and MR are involved in the regulation of cortisol release and coping with stress (De Kloet et al. 1998). MR activity governs a tonic hippocampal inhibitory control over the hypothalamus-pituitary-adrenal (HPA) axis; GR activity exerts a negative feedback on higher brain centres under conditions of high cortisol (De Kloet et al. 1998, Reul et al. 2000). Indeed, high cortisol levels, via GR activity, inhibit $\mathrm{CRH}$ and $\mathrm{ACTH}$ release from hypothalamus and pituitary gland respectively, to counteract the stress imposed (De Kloet et al. 1998). In fish, where such negative feedback has been described (Wendelaar Bonga 1997, Mommsen et al. 1999), neither the receptors involved are known nor are the signals precisely defined (i.e. is it cortisol, DOC or may be both).

We therefore investigated which corticosteroid receptors were present in common carp and where these receptors were located in the stress axis and focussed on CRH and ACTH cells and higher brain centres (telencephalic pallial neurons). Next, we determined mRNA expression of the three receptors (GR1, GR2 and MR) and sensitivity for cortisol by transactivation analysis to assign the possible differential functionality under basal or stress conditions (i.e. when plasma cortisol is low and high). Finally, we showed that corticosteroid mRNA expression in the stress axis could be manipulated by a chronic stress paradigm suggesting the involvement of all three receptors in stress axis regulation.

\section{Materials and Methods}

\section{Animals}

Common carp (Cyprinus carpio L.) were kept at $23{ }^{\circ} \mathrm{C}$ in recirculating u.v.-treated tap water at 'De Haar Vissen' in Wageningen. Fish were fed with dry food pellets (Promivi, Rotterdam, The Netherlands) at a daily maintenance ration of $0.7 \%$ of their estimated body weight. The cross ' $R 3 \times \mathrm{R} 8$ ' is offspring of Hungarian (R8) and Polish (R3) strains (Irnazarow 1995). Experimental repeats were performed with fish from different batches of eggs. All experiments were performed according to national legislation and were approved by the institutional Ethical Committee.

\section{Identification of GR1, GR2 and MR genes}

We screened the Ensembl zebrafish genome database with sequences of mammalian GR and MR genes, using the basic local alignment search tool (BLAST) algorithm. This screen revealed one GR gene and one MR gene. These genes were incorporated in separate multiple sequence alignments, using CLUSTALW (Chenna et al. 2003); for both the GR and MR, genes of several species were used. Primers were designed in regions of high amino acid identity. We obtained partial cDNA sequences from a $\lambda Z A P$ cDNA library of carp brain. The corresponding fulllength sequences were obtained by RACE (Invitrogen). PCR was carried out as described previously (Huising et al. 2004) and the sequences were determined from both strands.

\section{Probe synthesis}

Digoxygenine (DIG)-labelled carp GR1, GR2 and MR probes (Table 1) were synthesised from a PGEMTeasy (Promega) vector with the respective inserts by the use of a DIG RNA-labelling kit according to the manufacturer's instructions (Roche). The GR1 vector contained a 474 base pairs insert, the GR2 vector a 509 base pairs insert and the MR vector a 827 base pairs insert (primers shown in Table 1). Proper probe labelling was confirmed by the northern blotting. Probes were constructed in the $\mathrm{AB}$ domain, the least conserved region, to avoid crossreactivity between probes (Fig. 1).

\section{Tissue and section preparation}

Nine-month-old carp (150-200 g) was anaesthetised with $0 \cdot 2 \mathrm{~g} / 1$ tricaine methane sulfonate (TMS) (Cresent Research Chemicals, Phoenix, AZ, USA) buffered with $0 \cdot 4 \mathrm{~g} / 1 \mathrm{NaHCO}_{3}$ (Merck). Blood was collected by puncture of the caudal vessels 
Table 1 Primers used to generate in situ hybridisation probes

\begin{tabular}{|c|c|c|}
\hline & Sequence & Amplicon length $(b p)$ \\
\hline \multicolumn{3}{|l|}{ Gene } \\
\hline \multirow[t]{2}{*}{ GR1 } & FW: 5'-AGC-ATC-CAG-GCC-CCT-GAC-AC-3' & 474 \\
\hline & RV: 5'-AGG-ACC-ACC-CAT-CCC-TGA-CAT-CTG-3' & \\
\hline \multirow[t]{2}{*}{ GR2 } & FW: 5'-CCT-TCA-GTG-GAC-TCC-CTG-ATT-G-3' & 509 \\
\hline & RV: 5'-GAA-GTG-GTG-ACG-CCG-CAG-ATG-TTA-A-3' & \\
\hline \multirow[t]{2}{*}{ MR } & FW: 5'-CAY-YGT-GGG-GTC-ACC-TCC-AC-3' & 827 \\
\hline & RV: 5'-TCC-CTT-GCG-CTC-CAA-TCT-GG-3' & \\
\hline
\end{tabular}

using a heparinised (Leo Pharmaceuticals Products, Ltd, Weesp, The Netherlands) syringe fitted with a 21 gauge needle. Next, fish were killed by spinal transsection, and organs and tissues for RNA extraction were carefully removed, snap frozen in dry ice or liquid $\mathrm{N}_{2}$, and stored at $-80{ }^{\circ} \mathrm{C}$. Organs for in situ hybridisation were removed and fixed overnight in 4\% freshly prepared paraformaldehyde (PFA) in PBS. Next, the tissues were transferred to $1 \cdot 5 \%$ agarose in $15 \%$ sucrose in PBS, snap frozen in liquid $\mathrm{N}_{2}$ and stored at $-80^{\circ} \mathrm{C}$. Serial $7 \mu \mathrm{m}$ cryostat sections were made (Frigocut 2800, Reichert-Jung) and mounted on poly-L-lysine coated microscope slides $(\mathrm{BDH}$ Laboratory Supplies, Poole, UK).

\section{In situ hybridisation}

In situ hybridisation was adapted from Engelsma et al. (2001) and included a proteinase $\mathrm{K}(5 \mu \mathrm{g} / \mathrm{ml})$ (Promega) treatment for $10 \mathrm{~min}$ at $37^{\circ} \mathrm{C}$ to improve probe accessibility and a $10-\mathrm{min}$ exposure to $0 \cdot 25 \%$ acetic acid anhydride in $0 \cdot 1 \mathrm{M}$ triethanolamine (TEA) to stop RNAse activity. Probes (sense $0.5 \mathrm{ng} / \mu \mathrm{l}$ and antisense $1.5 \mathrm{ng} / \mu \mathrm{l})$ were dissolved in $\mathrm{Hyb}^{+}$buffer with $2 \%$ blocking reagent (Roche Applied Science) and denatured for $5 \mathrm{~min}$ at $80^{\circ} \mathrm{C}$, added to every glass slide, covered with parafilm and incubated overnight at $55^{\circ} \mathrm{C}$. $\mathrm{Hyb}^{+}$buffer was replaced with $4 \times \operatorname{SSCT}(4 \times$ SCC with $0 \cdot 01 \%$ Tween 20$)$ buffer and sections were rinsed $(2 \times 15 \mathrm{~min})$ in $4 \times \mathrm{SSCT}$ buffer at $60^{\circ} \mathrm{C}$. An RNAse treatment with $10 \mathrm{ug} / \mathrm{ml}$ RNAseA (Qiagen) for $30 \mathrm{~min}$ at $37^{\circ} \mathrm{C}$ removed unbound RNA fragments. Next, slides were washed $(2 \times$ with $2 \times \mathrm{SSCT}$, for $5 \mathrm{~min})$ at $60^{\circ} \mathrm{C}$, once with $1 \times$ SSCT for $10 \mathrm{~min}$ at $60^{\circ} \mathrm{C}$, once with $0.5 \times$ SSCT for $10 \mathrm{~min}$ at $60{ }^{\circ} \mathrm{C}$ and finally once with $0 \cdot 1 \times \mathrm{SSCT}$ for $30 \mathrm{~min}$ during which the samples were allowed to cool to room temperature. Washing and colour reaction were performed as described previously (Engelsma et al. 2001).

\section{Immunohistochemistry}

The tissue on glass slides was first fixed in 4\% PFA in PBS for $15 \mathrm{~min}$. The slides were washed once with PBST for $5 \mathrm{~min}$ and once with aquadest for $5 \mathrm{~min}$. Subsequently, they were incubated $10 \mathrm{~min}$ with methanol plus $0 \cdot 3 \% \mathrm{H}_{2} \mathrm{O}_{2}$, after which the slides were rinsed twice for $10 \mathrm{~min}$ in PBST. Subsequently, non-specific antigenic sites were blocked with $10 \%$ normal goat serum (NGS) in PBS for $30 \mathrm{~min}$. The slides were incubated overnight with polyclonal antiserum against $\mathrm{GH}$ $(1: 4000)$ or ACTH $(1: 2000)$ in PBS with $10 \%$ NGS. The next day the slides were rinsed twice for $10 \mathrm{~min}$ in PBST and incubated for $1 \mathrm{~h}$ with goat anti-rabbit secondary antibody at a dilution of 1:200.

\section{Imaging}

Pictures were taken with Zeiss Axiovert tv 135 microscope with a 5.0 Q-imaging colour camera and Leitz orthoplan cool snap colour camera (Roper Scientific). The pictures were edited (cropped and background colour compensation) using Adobe Photoshop.

\section{Stress experiments}

Restraint stress Prolonged restraint ( $24 \mathrm{~h}$ ) was given by netting the fish and suspending the nets with the fish in the tanks (Huising et al. 2004). After $24 \mathrm{~h}$, the experimental group was transferred all at once to a tank with $0.2 \mathrm{~g} / 1$ TMS, resulting in rapid ( $<1 \mathrm{~min}$ ) and deep anaesthesia prior to blood sampling and killing. A control group was housed in an identical tank but left undisturbed. Control fish were sampled following rapid netting and anaesthesia, immediately before sampling of the experimental group.

Cold water stress Fish were netted and transferred from a tank with $23{ }^{\circ} \mathrm{C}$ water to an identical tank with $10{ }^{\circ} \mathrm{C}$ water, and left there for $15 \mathrm{~min}$, after which they were returned to their original tank. This transfer was repeated thrice a day for 3 days. On day 4 , the fish were transferred once more and sampled $30 \mathrm{~min}$ after return to their original (warm) tank. For sampling, fish of a tank were all at once transferred to a tank with $0.2 \mathrm{~g} / 1$ TMS, resulting in rapid anaesthesia. Shamtreated fish were housed in identical tanks and transferred as mentioned above, but to tanks with $23{ }^{\circ} \mathrm{C}$ water. Control fish were housed in identical tanks and left undisturbed. The sham and control fish were sampled just before sampling of the experimental fish.

\section{Physiological parameters and plasma hormone determination}

Freshly collected, heparinised blood was centrifuged for $10 \mathrm{~min}$ at $2000 \mathrm{~g}$ at $4{ }^{\circ} \mathrm{C}$, after which plasma was transferred to a new 
GR1

GR2

MR

GR1

GR2

MR

GR1

GR2

MR

GR1

GR2

MR

GR1

GR2

MR

GR1

GR2

MR

GR 1

GR2

MR

GR1

GR2

MR

GR1

GR2

MR

GR1

GR2

MR

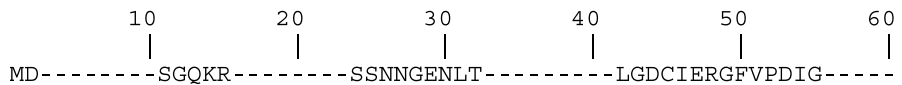

MDQG - - GLTNGAKRD- - - DHLNTLDYSNSP - - - - - - - VEGILRSGIQSAMP - - - METKRYQSYREGANAENKLAQMPNTMDYCCSAEEHLTNSDMLMDNVNS SNAPNMP SVCKD * :
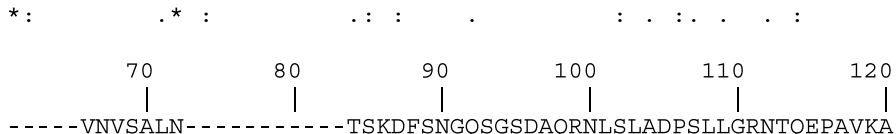
NNFKTTETTMLRVNQNQPLLFPSFNNSFQNRKSETDS - KELSKTVAESMGLYMNAAREAD

\begin{tabular}{rrrr|r|}
130 & 140 & 150 & 160 & 170
\end{tabular} VGKEQR - - - - AHQHQTLGAFTLGDSFSSLEAS IADLNSTSPSVDSLIGGMDPNLFPLKT FGFSQQGTAGGQGSPQKLYPLSGRANEDSQSRTTGSPKMKAPPASFPPGAQLPNGRPQEC

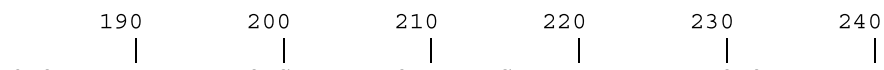
EQFSPMEKDRLDFP - - - SYGHMDKELDS - NERVIGDNT IDILKDLDLPDSLSDLNELYVA EEYSLMDKGDMDLDQ - DSFGP IGKDGDVDNHKLF SDNTLDLLQDFELDGSP SDF - - - YGA AVVSASVPSAMAATLSCSTDGSGPMSSPTGHNMVSSTTSPTFFDSDCPSLASTHTNLIQG

*. :

\begin{tabular}{c|c|c|c|c|}
250 & 260 & 270 & 280 & 290 \\
$\mid$ & $\mid$ & $\mid$ & $\mid$
\end{tabular}

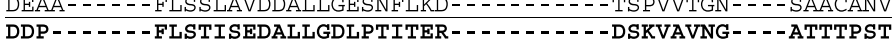
QHTS PNTCSPVKSSVVGSPPLASPLSVIKSPVSSPHS IGSVSSPLSCNTNMRSSVSSPTT
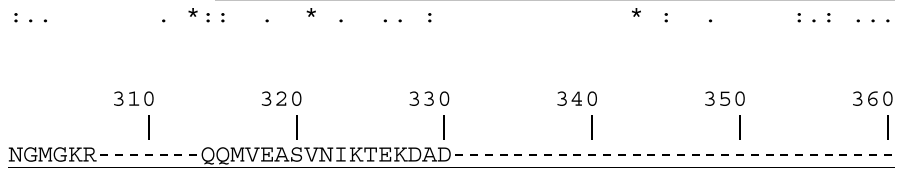

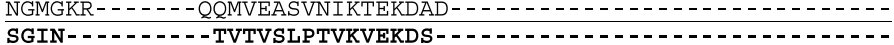
YGGNTSNIRPS ISSPPTVGSMTMS SPRNSSRGFSVSSPPSGLGLVQNDVNSPESREHDFK

*. . . . . . : : :

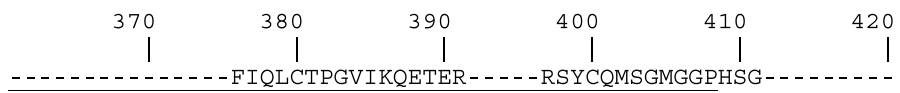
- - - - - - - - - - IIQLCTPGVIKQENNGG- - - TKYCQASLHSTPIN- - - - - - - AFEFPKVENVDGEIFNIGLDAMGVAKYI KNEPGTDYRSMCLGSSKSAMPHSPFITHIKTE

* $*$ : * * . : * *

$\begin{array}{llllll}430 & 440 & 450 & 460 & 470 & 480\end{array}$ - - - - PTTLGDMGGQGYHYGAN - - - TASAVSLPDQKPPFGLF - - - - SPLPTLSDGWVRGN - - - - - ICGVTTSVGQSFLIGTSP - STAAVSQQKDQKPVFNVY - - - - TPVTSSEDGWGRGY PNREVTCSNLQFVEPQHSLGCFPSTETTYLSLRDNIDEYSLSGILGPPVLSLNGNYEPGV

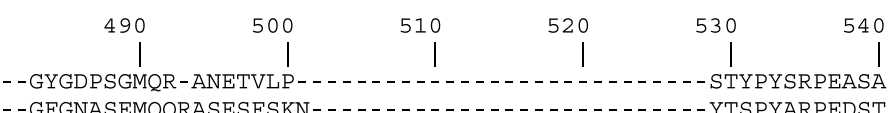
FPNNGLPKGI KQETSDGSYYQENNNVPTSAIVGVNSGGHSFHYQIGAQGTMSFSRHNLRD * . . : : : . : * .: : :

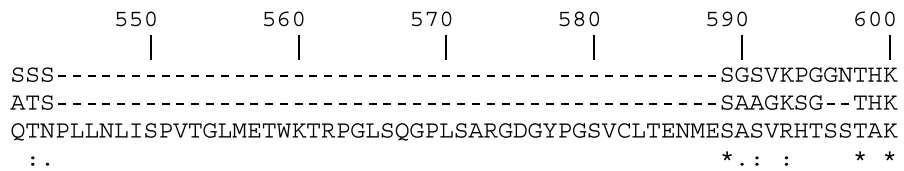

Figure 1 (continued) 


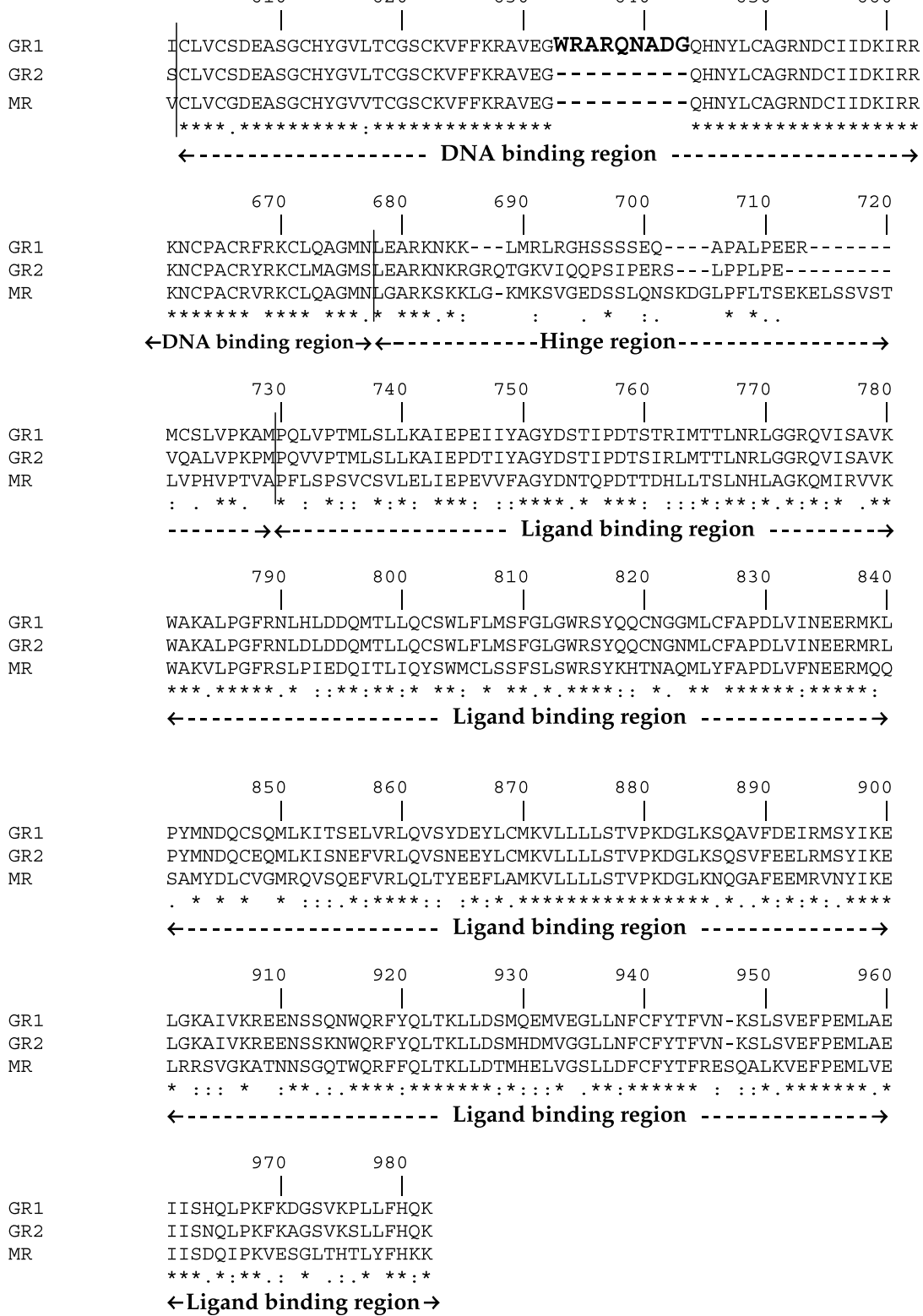

Figure 1 Alignment of corticosteroid receptor sequences of carp. Locations of probes are indicated; GR1 is underlined, GR2 is shown in bold and MR is shown in grey. Different regions of the receptors are indicated below the alignment; the transactivation region is located $\mathrm{N}$-terminally from the other regions and has not been indicated. The nine amino acid insert present in the DNA-binding region of GR1 is shown in a larger, bold font. Asterisks indicate conserved amino acids, double points indicate replacement by amino acids with high similarity and single points indicate replacement with amino acids of low similarity.

tube and stored at $-20^{\circ} \mathrm{C}$. Cortisol was measured by RIA (Arends et al. 1998), with a commercial antiserum (Bioclinical Services Ltd, Cardiff, UK). All constituents were in phosphateEDTA buffer (0.05 $\mathrm{M} \mathrm{Na}_{2} \mathrm{HPO}_{4}, 0 \cdot 01 \mathrm{M} \mathrm{Na}_{2}$ EDTA, 0.003 M $\mathrm{NaN}_{3}, \mathrm{pH} 7 \cdot 4$ ). Ten microlitre samples or standards in RIA buffer (phosphate-EDTA buffer containing 0.1\% 8-anilia-1naphthalene sulphonic acid and $0 \cdot 1 \% \mathrm{w} / \mathrm{v}$ bovine $\gamma$-globulin) were incubated with $100 \mu$ lantiserum (in RIA buffer containing $0 \cdot 2 \%$ normal rabbit serum) for $4 \mathrm{~h}$. The samples were incubated overnight with $100 \mu \mathrm{l}$ iodinated cortisol 1700 c.p.m./tube $\left({ }^{125}\right.$ I-labeled cortisol, Amersham) and $100 \mu$ goat anti-rabbit $\gamma$-globulin (in RIA buffer). Bound and free cortisol in the assay were separated by the addition of $1 \mathrm{ml}$ ice-cold precipitation buffer (phosphate-EDTA buffer containing 2\% w/v bovine serum albumin and $5 \% \mathrm{w} / \mathrm{v}$ polyethylene glycol). Tubes were centrifuged at $4{ }^{\circ} \mathrm{C}(20 \mathrm{~min}$ at $2000 \mathrm{~g})$, the supernatant aspirated and counted in a gamma counter (1272 clinigamma, LKB, Turku, Finland). Plasma glucose and $\mathrm{Na}^{+}$levels were measured 
with a Stat Profile pHOx Plus L Analyser (Nova Biochemical, Waltham, USA).

\section{RNA isolation}

RNA was isolated from tissues after extraction in Trizol reagent (Invitrogen), as suggested by the manufacturer. Total RNA was precipitated in isopropanol, washed with 75\% ethanol and dissolved in nuclease-free water. RNA of separated pituitary glands (pars distalis and pars intermedia separate) was isolated as described by the RNeasy Mini Kit (Qiagen) strictly according to the manufacturer's instructions. RNA concentrations were measured by spectrophotometry and integrity was ensured by analysis on a $1.5 \%$ agarose gel before proceeding with cDNA synthesis.

\section{DNAse treatment and first strand $c D N A$ synthesis}

For each sample, a '- RT' (non-reverse transcriptase) control was included. One microlitre $10 \times$ Dnase-I reaction buffer and $1 \mu \mathrm{l}$ Dnase-I (Invitrogen, 18068-015) were added to $1 \mu \mathrm{g}$ total RNA and incubated for $15 \mathrm{~min}$ at room temperature in a total volume of $10 \mu \mathrm{l}$. DNase I was inactivated with $1 \mu \mathrm{l}$ $25 \mathrm{mM}$ EDTA at $65^{\circ} \mathrm{C}$ for $10 \mathrm{~min}$. To each sample, $300 \mathrm{ng}$ random hexamers (Invitrogen, 48190-011), $1 \mu \mathrm{l} 10 \mathrm{mM}$ dNTP mix, $4 \mu \mathrm{l} 5 \times$ first strand buffer, $2 \mu \mathrm{l} 0 \cdot 1 \mathrm{M}$ dithiothreitol and 40 Units RNAse Out (Invitrogen 10777-019) were added and the mix was incubated for $10 \mathrm{~min}$ at room temperature and for an additional $2 \mathrm{~min}$ at $37^{\circ} \mathrm{C}$. To each sample (not to the '- RT' controls), $200 \mathrm{U}$ Superscript-II RNase $\mathrm{H}^{-}$reverese transcriptase (RT; Invitrogen, 18064-014) was added and the reaction mixtures were incubated for $50 \mathrm{~min}$ at $37^{\circ} \mathrm{C}$. All reaction mixtures were filled up with demineralised water to a final volume of $100 \mu \mathrm{l}$ and stored at $-20{ }^{\circ} \mathrm{C}$ until further use.

\section{Real-time quantitative PCR}

PRIMER EXPRESS (Applied Biosystems, Foster City, CA, USA) and PRIMER 3 software were used to design primers for use in real-time quantitative PCR (RQ-PCR) (Table 2). For RQ-PCR, $5 \mu \mathrm{l}$ cDNA and forward and reverse primers (300 nM each) were added to $12 \cdot 5 \mu \mathrm{l}$ Quantitect Sybr Green PCR Master Mix (Qiagen) and filled up with demineralised water to a final volume of $25 \mu \mathrm{l}$. RQ-PCR $\left(15 \min 95^{\circ} \mathrm{C}\right.$, 40 cycles of $15 \mathrm{~s}$ at $94^{\circ} \mathrm{C}, 30 \mathrm{~s}$ at $60^{\circ} \mathrm{C}$, and $30 \mathrm{~s}$ at $72{ }^{\circ} \mathrm{C}$ followed by $1 \mathrm{~min}$ at $60^{\circ} \mathrm{C}$ ) was carried out on a Rotorgene 2000 real-time cycler (Corbett Research, Sydney, Australia). Raw data were analysed by use of the comparative quantitation of the Rotor-gene Analysis Software V5.0. Basal gene expression in organs and tissues of adult carp was determined as a ratio of target gene versus reference gene and was calculated according to the following equation: Ratio $=\left(E_{\text {reference }}\right)^{C_{\mathrm{t}} \text { reference }} /\left(E_{\text {target }}\right)^{C_{\mathrm{t}} \text { target }}$, where $E$ is the amplification efficiency and $C_{\mathrm{t}}$ is the number of PCR cycles needed for the signal to exceed a predetermined threshold value. Expression following $24 \mathrm{~h}$ of restraint or cold water transfer was determined relative to the expression of non-restraint control fish according to the following equation (Pfaff 2001), Ratio $=\left(E_{\text {target }}\right)^{C_{\mathrm{t}} \text { target(control-sample) }}$ / $\left(E_{\text {reference }}\right)^{C_{\mathrm{t}} \text { reference(control-sample) }}$. Dual internal reference genes (40S ribosomal protein and $\beta$-actin) were incorporated in all RQ-PCR experiments; results were similar following standardisation to either gene. '- RT' controls were included in all experiments and no amplification above background levels was observed. Non-template controls were included for each gene in each run and no amplification above background levels was observed. Specificity of the amplification was ensured by checking the melting temperature and the profile of each melting curve. The product of each template was checked at least once by sequencing.

\section{Transactivation assay}

Clones encoding full-length open reading frame of common carp GR 1 and GR 2 were excised from pGEM-Teasy vector by EcoR 1 and BamH1 and ligated into pcDNA3 expression vector cut with the same enzymes. Orientation and quality of the insert was confirmed by sequencing. COS-7 cells (derived from

Table 2 Primers used for gene expression studies

\section{Sequence}

Amplicon length (bp)

113

110

117

130

89

69
Genbank acc. no.

AJ879149

AM183668

AJ783704

X52881

M24113

AB012087 
African green monkey kidney) were cultured as described previously (Sturm et al. 2005). Cells were transiently transfected using calcium precipitation method (Sambrook \& Russell 2001), with the cells growing in log phase at 30-50\% confluence. Cells were co-transfected with the following plasmids: expression vector with the appropriate hormone receptor cDNA $(1 \mu \mathrm{g} / 24$-well plate), reporter plasmid pFC31Luc that contains the mouse mammary tumour virus promoter upstream of the luciferase gene $(10 \mu \mathrm{g} / 24$-well plate); pSV $\beta$ (Clontech), a second reporter plasmid under control of the SV40 promoter and serving as a control for the transfection efficiency $(2 \mu \mathrm{g} / 24-w e l l$ plate); and finally pBluescript (Clontech) $(7 \mu \mathrm{g} / 24-$ well plate), an irrelevant plasmid to increase transfection. Sixteen hours after transfection, medium was renewed and cortisol added from 1000-fold concentrated stock solution in ethanol. After 36-h incubation, cells were harvested using reporter lysis buffer (Promega) following the manufacturer's instructions; luciferase and $\beta$-galactosidase activities were determined as described previously (Bury et al. 2003). In addition to solvent controls (receiving only ethanol carrier instead of hormone), cells were transfected with an empty expression vector as control for luciferase activity in the absence of hormone receptor DNA. Experiments were repeated thrice independently, with triplicate cell cultures per treatment. Luciferase activity was corrected for 'well-specific' transfection efficiency (determined by $\beta$-galactosidase activity) and then expressed as percentage luciferase activity observed in cells treated with $10^{-7} \mathrm{M}$ cortisol.

Half maximum activation concentration of ligand $\left(\mathrm{EC}_{50}\right)$ in the transactivation assay were assessed by fitting the data to a single ligand binding model using the Sigma plot $^{\mathrm{R}}$ software. Only converging data were included in data sets presented. Ligands were tested in the range of $10 \mathrm{pM}$ to $1 \mu \mathrm{M}$. Data were normalised to maximum (100\%) response and corrected for blanks prior to kinetic analysis.

\section{Bioinformatics}

Sequences were retrieved from the Swissprot, EMBL and GenBank databases using SRS and/or BLAST (Altschul et al. 1997). Multiple sequence alignments were carried out using CLUSTALW (Chenna et al. 2003). Calculation of pairwise amino acid identities was carried out using the SIM ALIGNMENT tool (Huang \& Miller 1991). Phylogenetic and molecular evolutionary analyses were conducted using MEGA version 3.1 (Kumar et al. 2004). Phylogenetic tree was constructed based on the neighbour-joining method using the Poisson correction for evolutionary distance (Nei \& Kumar 2000). Reliability of the tree was assessed by bootstrapping, using 1000 bootstrap replications.

\section{Statistical analysis}

Statistic analysis was performed with SPSS 12.0.1 software (SPSS Inc., Chicago, IL, USA). Following ANOVA, differences between treatments were assessed by MannWitney $U$ test, and $P<0.05$ was accepted as fiducial limit. For RQ-PCR data, tests were performed for both internal reference genes ( $\beta$-actin and $40 S$ ) and statistical significance is reported only if both reference genes showed a significant effect, where $\star_{\text {indicates }} P<0.05$ and $\star \star$ indicates $P<0.01$.

\section{Results}

\section{CR characterisation}

Cloning and characterisation of the MR and GR genes Full-length sequences of one MR and two different GR genes were obtained by homology cloning using a common carp brain cDNA library. The first GR gene (GR1; acc. no. AJ 879149) comprises 2190 nucleotides and encodes a protein of 730 amino acids. The second gene (GR2; acc. no.

Carp GR1
Carp GR2
Carp MR
Zebrafish GR
Zebrafish GR
Human GR
Human MR
Figure 2 Similarities between the receptor domains (AB, transactivation region; C, DNA-binding region;
D, hinge region; $E$, ligand binding region) of the common carp and other vertebrate corticosteroid receptors.
Percentage of amino acid identity of the different domains is shown in the boxes. Amino acid length of
particular domains is represented by the length of boxes and is also mentioned. Total length of each protein is
shown at the right. Grey bar indicates nine amino acid insert as a result of alternative splicing.


AM183668) contains an open reading frame of 2235 nucleotides and encodes a protein of 745 amino acids (Fig. 1). The predicted amino acid identity of these two GRs is $57 \%$; both gene products show moderate sequence (45-60\%) identity when compared with other teleostean fish and mammalian GR genes (Fig. 2). The MR gene (acc. No. AJ783704) has an open reading frame of 2913 nucleotides that codes for a 971 amino acids protein. The predicted MR amino acid sequence shows relatively high (65-90\%) sequence identity to the other teleostean fish MR sequences and moderate $(\sim 50 \%)$ sequence identity to the African clawed frog (Xenopus laevis) and mammalian MR sequences.

When the protein domains of the receptors (GRs and MR) are compared among different species, 85-100\% sequence identity is found for the DNA-binding domain. For the ligand-binding domain (LDB), 50-60\% sequence identity is

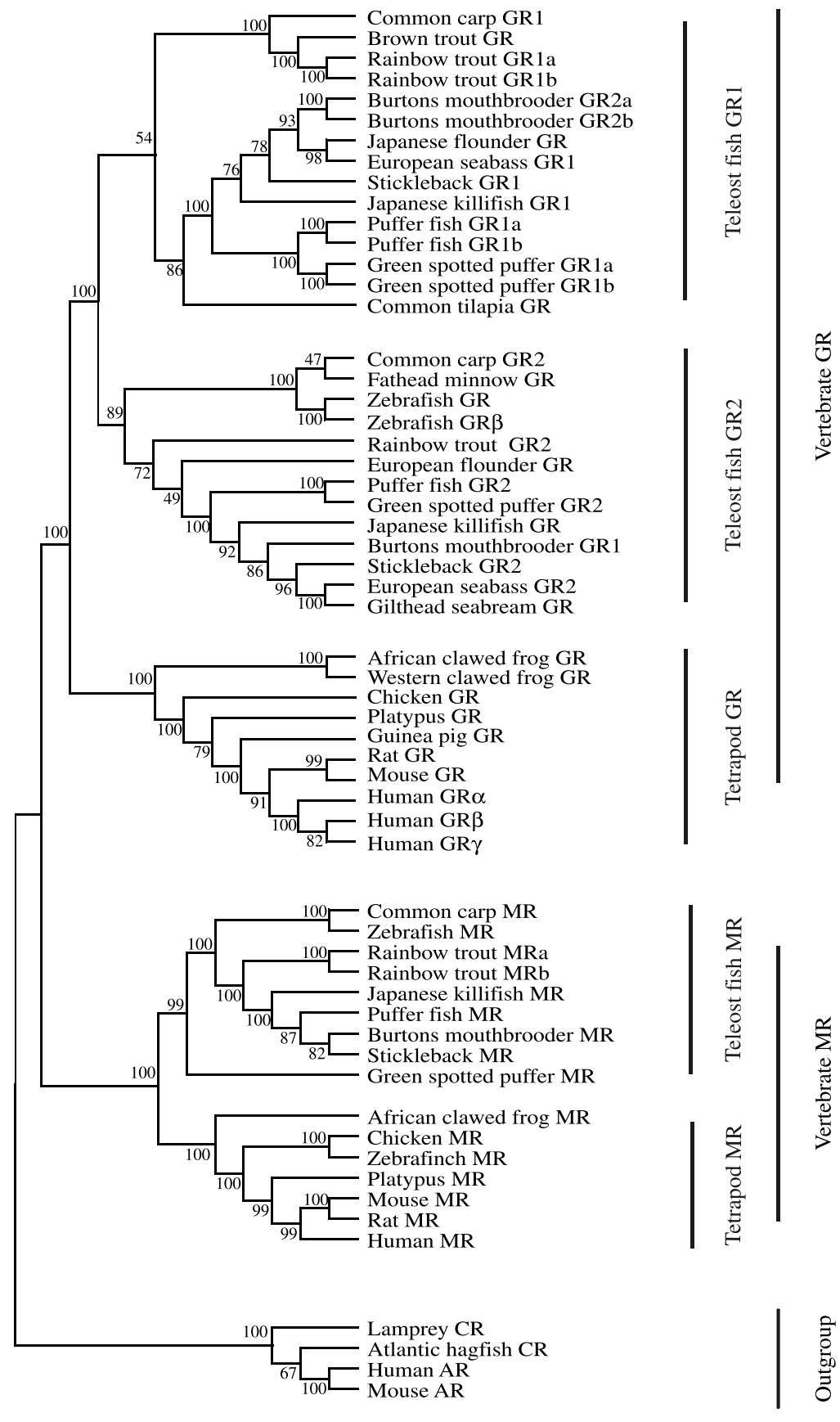


found when GRs are compared with MRs between species, and 70-90\% when LDBs of either GRs or MR of individual species are compared (Fig. 2). The N-terminal domains of GRs and MRs constitute the most variable region. Alignment of carp GR and MR genes yields low sequence conservation (28\% for GR1 compared with GR2 and $<15 \%$ for MR compared with either of the GRs; Fig. 1).

Phylogenetic analysis The neighbour-joining phylogenetic tree for corticosteroid receptor proteins (Fig. 3) resulted in a predicted cluster of GRs and MRs on separate branches together with mammalian orthologues; androgen and corticosteroid receptors from jawless fish represent an out-group. Within both the MR and GR branch, teleostean and tetrapod proteins form separate clades. The teleostean GR clade has a subdivision as a result of duplication of the GR gene.

\section{Expression of mRNAs for corticosteroid receptors} Expression of GR1, GR2 and MR genes in the brain (without hypothalamus and pituitary gland), ventral hypothalamus, pituitary gland of healthy and non-stressed carp was quantitated by real-time PCR shown in Fig. 4. The highest GR expression was found in the brain and hypothalamus. Expression of GR1 and GR2 genes was generally comparable; in the brain, however, GR1 expression was higher than GR2 expression. Receptor expression abundance in pituitary tissue was about half that was seen in the brain or hypothalamus. The MR gene also showed an about $50 \%$ lower expression level in pituitary tissue compared with the brain and hypothalamus (Fig. 4a).

To discriminate gene expression levels in the pars distalis (pro-opiomelanocortin, POMC cells producing ACTH) and pars intermedia (POMC cells producing melanocyte-stimulating hormone $(\mathrm{MSH})$ ), we dissected pituitary glands and confirmed tissue separation by assay of prolactin mRNA expression, a marker for the rostral pars distalis (RPD, insert Fig. 4b). GR1 and GR2 mRNA expression was significantly $(P<0 \cdot 01)$ higher in pituitary pars distalis compared with pars intermedia. No such difference was observed for MR mRNA (Fig. 4b).

CR localisation The localisation of mRNA expression was further studied by in situ hybridisation. In the telencephalon, mRNA expression of all three receptors was detected, predominantly in the outer pallial layers. In other brain areas, GR1 and GR2 show the same distribution pattern, although relative expression levels were different, whereas MR mRNA showed a less wide distribution. In transverse sections of the hypothalamus, mRNA expression of all the three receptors was observed in the magnocellular part of the NPO (as assessed by comparison with paramedian sagittal slides (Huising et al. 2004)); expression was less pronounced in the parvocellular part (Fig. 5). In the pituitary pars intermedia, GR mRNA expression was low. In the pars distalis, strongest GR expression was found in the proximal pars distalis, in GH-producing cells. In the rostral pars distalis, ACTH cells express both corticosteroid receptors GR 1 and GR2 and to a far higher degree than the prolactin cells (Fig. 6).

Transactivation activity GR2 was more sensitive to the different hormones tested than GR1. For both receptors, dexamethasone was the strongest agonist tested, followed by cortisol, deoxycortisol and corticosterone. Finally, aldosterone and DOC were very weak agonists. The physiologically important stress hormone cortisol was chosen as ligand to

Figure 3 Phylogenetic tree comparing the amino acid sequences of the vertebrate corticosteroid receptors. This tree was generated with MEGA version 3.1 software using the neighbour-joining method. Reliability of this tree was assessed by bootstrapping using 1000 bootstrap replications; values in percentage are indicated at branch nodes. Atlantic hagfish and sea lamprey corticosteroid receptors (CR) and human and rat androgen receptors (AR) were used as out-group. Common carp (C. carpio) GR1; AJ879149, GR2; AM183668, Rainbow trout (Oncorhynchus mykiss) GR1; P49843, GR2; AY4953720, Burton's mouthbrooder (Haplochromis burtoni) GR1; AF263738, GR2a; AF263739, GR2b; AF263740, Zebrafish (Danio rerio) GR2; EF436284, GR2ß; EF436285 Japanese flounder (Paralichthys olivaceus) GR; (O73673), European sea bass (Dicentrarchus labrax) GR1; AY549305, GR2; AY619996, Brown trout GR (Salmo trutta); AY863149, Fathead minnow (Pimephales promelas) GR; AY533141, Puffer fish (Fugu) (Takifugu rubripes) GR1; GENSCAN00000003615 (scaffold 1264) \& GENSCAN00000029451 (scaffold 4328), GR2; SINFRUG00000143550 (scaffold 59), Green spotted puffer (Tetraodon) (Tetraodon nigroviridis) GR1; GIDT00024792001 (Chr. 7), GR2; GSTENG00017027001 (Chr. 1) Stickleback (Gasterosteus aculeatus) GR1; ENSGACP00000027400, GR2; ENSGACP00000024074, Japanese Killifish (Medaka) (Oryzias latipes) GR1; ENSORLP00000001939, GR2; ENSORLP00000007570, Mozambique or common tilapia (Oreochromis mossambicus) GR; BAA23662, African clawed frog (Xenopus laevis) GR; P49844, Western clawed frog (X. tropicalis) GR; CR848477, Chicken (Gallus gallus) GR; ENSGALP00000011948 (Q8JHA4 partial), Platypus (Ornithorhynchus anatinus) GR; ENSOANP00000009152, Pig (Sus scrofa) GR; AY779185, Cow (Bos taurus) GR; AY238475, Guinea pig (Cavia porcellus) GR; P49115, Mouse (Mus musculus) GR; P06537, Rat (Rattus norvegicus) GR; NP_036708, Human

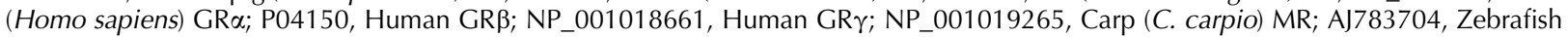
(D. rerio) MR; ENSDARP00000053817, Rainbow trout (O. mykiss) MRa; Y495584, MRb; AY495585, Burton's mouthbrooder (H. burtoni) MR; Q8JJ89, Puffer fish (Fugu) (T. rubripes) MR; NEWSINFRUP00000129848, Green spotted puffer (Tetraodon) (T. nigroviridis) MR; GSTENT00032894001, Stickleback (G. aculeatus)MR;ENSGACP00000022713, Japanese killifish (Medaka, O. latipes) MR; ENSORLT00000009439, Chicken (G. gallus) MR;ENSGALP00000016283 (Q8QHI2, partial), Platypus (O. anatinus) MR;

ENSOANT00000008378, African clawed frog (X. laevis) MR; BC081082, Mouse MR; XP_356093, Rainbow trout MR; AY495584, Human MR; M16801, Sea lamprey (Petromyzon marinus) CR; AY028457, Atlantic hagfish (M. glutinosa) CR; DQ382336 Mouse (M. musculus) AR; M37890 Human (H. sapiens) AR; P10275. NB: Burton's mouthbrooder nomenclature is different; GR1 has no splice variants (comparable with common carp and rainbow trout GR2) and GR2 has two splice variants (comparable with rainbow trout GR1); Burton's mouthbrooder GR2b has a nine amino acid insert. 
A Basal corticosteroid receptor expression in control fish

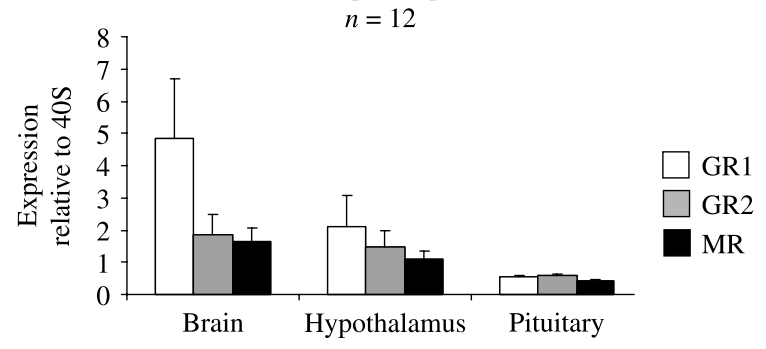

B Basal corticosteroid receptor expression in the pituitary

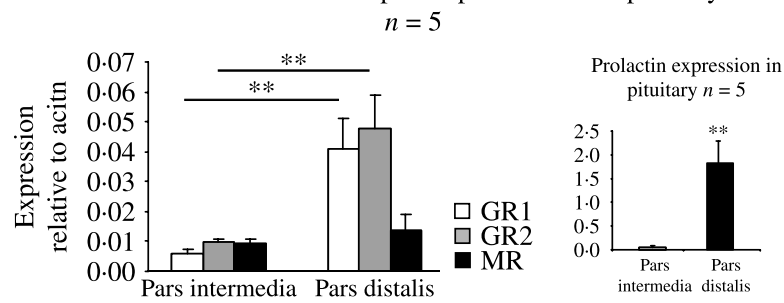

Figure 4 Basal corticosteroid receptor expression in stress axis of control fish (A). Comparison of quantitative real-time PCR data was based on samples of four untreated fish and controls from 24-h netting experiment $(n=4)$ and controls of the cold water transfer experiment $(n=4)$. Data are plotted as average of the mean of each of the three experiments relative to the housekeeping gene 40S; error bars indicate standard error of the means of these three experiments. NB: Gene expression data relative to housekeeping gene $\beta$-actin $(n=8)$ showed the same pattern (not shown). Basal corticosteroid receptor expression in different sections of the pituitary gland $(n=5)(B)$. Insert shows prolactin mRNA expression in different sections of pituitary.

compare sensitivity between the different receptors in a transactivation assay. Carp GR1 was less sensitive than the GR2, both to cortisol ( EC $_{50} 7 \cdot 1 \pm 2.9 \mathrm{nM}$ and $2 \cdot 4 \pm 0 \cdot 4 \mathrm{nM}$ for GR1 and GR2 respectively) and dexamethasone $\left(\mathrm{EC}_{50}\right.$ $2 \cdot 4 \pm 3 \cdot 8 \mathrm{nM}$ and $0.7 \pm 1 \cdot 4 \mathrm{nM}$ for GR1 and GR2 respectively) (Table 3). The carp $\mathrm{MR}$ has intermediate sensitivity for cortisol $\left(\mathrm{EC}_{50} 4 \cdot 1 \pm 2 \cdot 0 \mathrm{nM}\right)$ when compared with the GRs. The sensitivity of the MR to aldosterone and DOC was comparable and approximately tenfold higher than to cortisol.

\section{Physiology}

Corticosteroid receptor expression and stress To study the corticosteroid receptor expression after stress, we used two different stress paradigms. Restraint of carp for $24 \mathrm{~h}$ resulted in significantly elevated plasma cortisol and plasma glucose values as assessed upon completion of the treatment. Plasma sodium concentrations had significantly decreased in stressed animals, indicative of stress-related loss of integumental permeability to water and ions (Wendelaar Bonga 1997, Metz et al. 2003). Corticosteroid receptor expression in any of the tissues tested was not affected by this restraint. When fish were repeatedly subjected to temperature drops, they showed strongly elevated plasma cortisol levels and a down-regulation of mRNA expression of the GRs and MR in the brain; in hypothalamus and pituitary gland, no statistically significant changes were seen (Fig. 7).

\section{Discussion}

In vertebrates, corticosteroids are deeply involved in general metabolism, stress adaptation, reproduction, osmoregulation, growth and bone formation. The phenomenal pleiotropy of corticosteroids would suggest radiation of multiple isoforms and splice variants for their receptors during evolution. Indeed, research on mammals has focused on isoform and splice variant incidence of cortisol receptors (GR receptors, GRs) and how these variants translate for instance into regulation of the stress
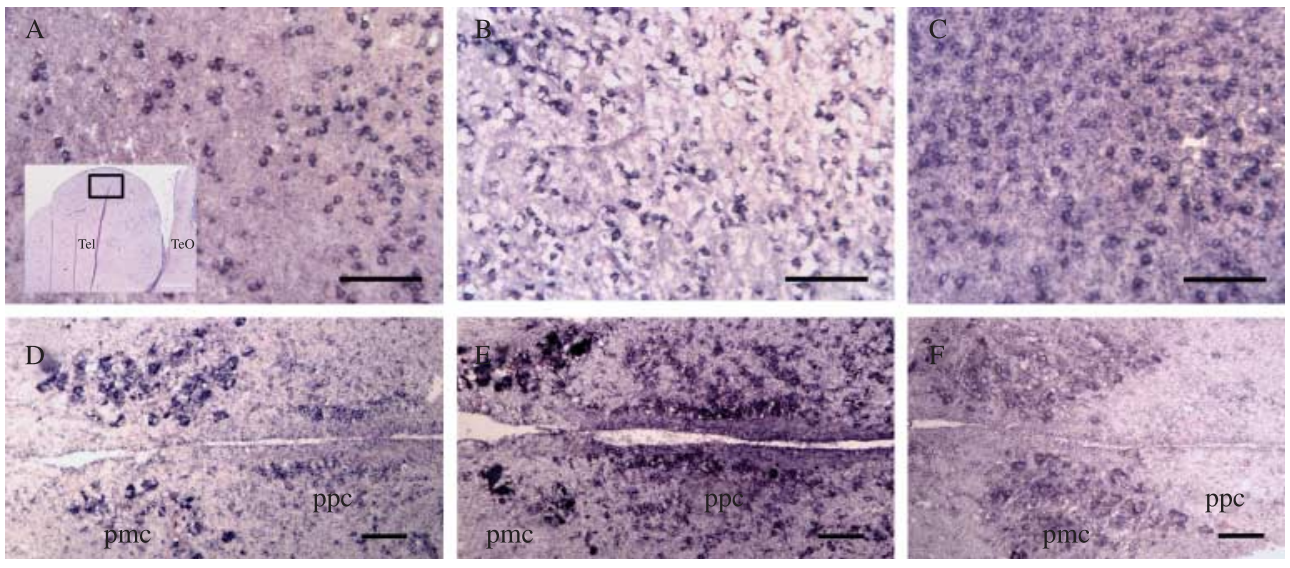

Figure 5 Localisation of GR1, GR2 and MR expression by ISH in cells of the telencephalon and the NPO. (A-C) telencephalon; $(A)$ insert, overview of the telencephalon with haematoxylin and eosin staining. Anti-sense probe for GR1 (A), GR2 (B) and MR (C). (D-F) NPO, nucleus pre-opticus of hypothalamus; anti-sense probe for GR1 (D), GR2 (E) and MR (F). GR1 with: Tel, telencephalon; TeO, tectum opticum; pmc, nucleus pre-opticus magnocellularis; ppc, nucleus pre-opticus parvocellularis. Scale bars indicate $500 \mu \mathrm{m}$ (A insert) or $100 \mu \mathrm{m}(\mathrm{B}-\mathrm{F})$. 

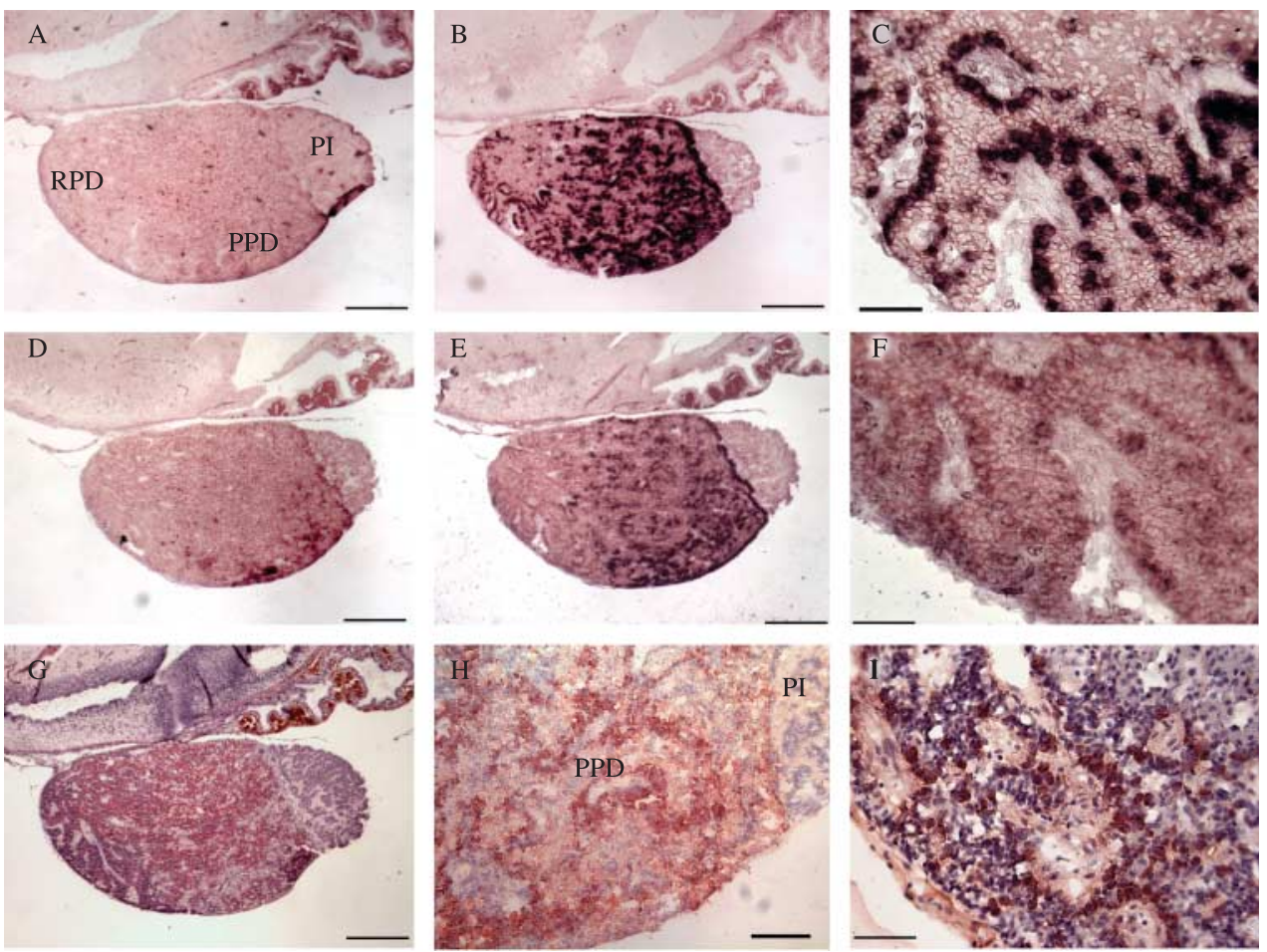

Figure 6 Localisation of GR1 and GR2 expression in the cells of pituitary. (A) Sense control for GR1, (B) antisense probe for GR1, and (C) detail of rostral pars distalis (RPD) with anti-sense probe for GR1. (D) Sense control for GR2, (E) anti-sense probe for GR2 and (F) detail of RPD with antisense probe for GR2.

(G) Overview of pituitary stained with haematoxylin and eosin, $(\mathrm{H})$ detail of proximal pars distalis (PPD) with antibody against $\mathrm{GH}$, and (I) detail of RPD with antibody against ACTH. PI, pars intermedia. Scale bars indicate $500 \mu \mathrm{m}(\mathrm{A}, \mathrm{B}, \mathrm{D}, \mathrm{E}$ and $\mathrm{G}), 50 \mu \mathrm{m}(\mathrm{H}), 100 \mu \mathrm{m}(\mathrm{C}, \mathrm{F}$ and $\mathrm{I})$.

axis. The extant teleostean fishes are representatives of the earliest true vertebrates and exhibit a complex receptor profile. With two genes encoding functionally different GRs, this system is even more complex than that observed in mammals, which warranted investigation into the role of these different receptors in stress axis regulation.

\section{CR characterisation}

Receptor evolution in fishes Different GR genes were demonstrated in distantly related teleostean species (Bury et al. 2003, Greenwood et al. 2003) and for that very reason not necessarily result from the tetraploidisation of common carp (Greenwood et al. 2003, Stolte et al. 2006). In the green-spotted puffer, two duplicates on different chromosomes are found that makes a single gene duplication less likely (Stolte et al. 2006). Moreover, all known teleostean GR1 proteins share a conserved insert of nine amino acids (WRARQNTDG, or Wrarqnadg in carp) in the DNA-binding domain which are not found in other vertebrates. We rate it highly unlikely that all teleosts independently duplicated a single gene and inserted every time again a nine amino acid sequence. Most convincing for this debate is that our phylogenetic analysis yields two distinct clades of GR genes in the teleostean lineage that argues against

Table 3 Transactivation capacity of corticosteroid receptors ${ }^{\mathrm{a}}$

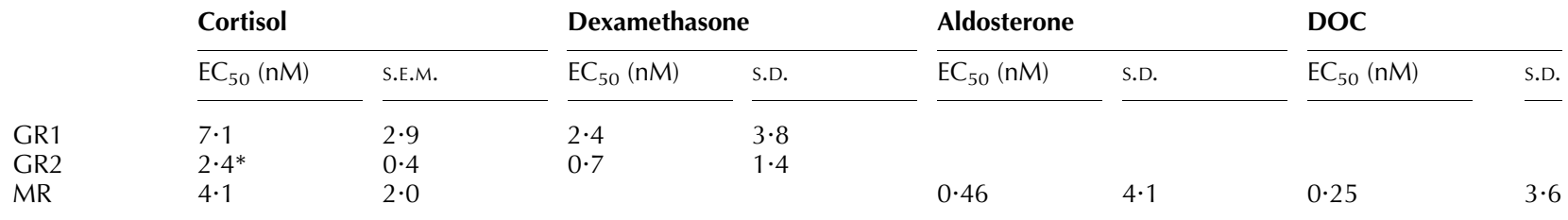

*GR2 is significantly more sensitive to cortisol than GR1 $(P<0 \cdot 05)$.

${ }^{a} \mathrm{EC}_{50}$ values of GR1, GR2 and MR for different hormones. Cortisol for GRs; average of three separate experiments with standard error of the mean; cortisol for $\mathrm{MR}$, dexamethasone, aldosterone and DOC; single experiments. DOC, 11-Deoxycorticosterone. 
A Corticosteroid receptor expression after $24 \mathrm{~h}$ restraint stress

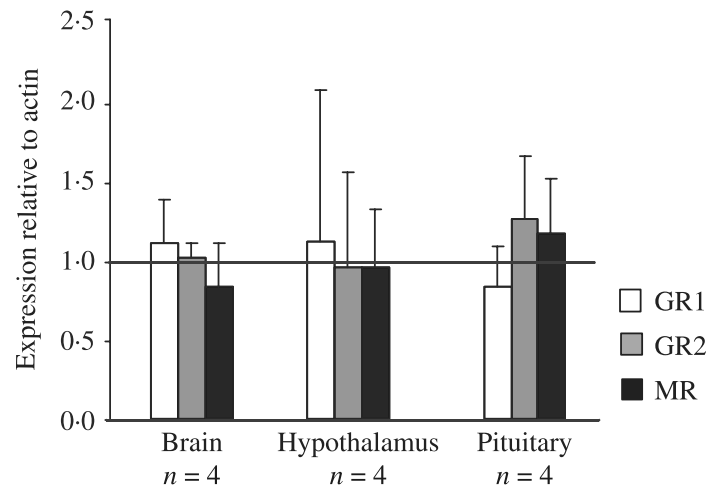

B

Corticosteroid receptor expression after cold transfer stress $\left(23-10^{\circ} \mathrm{C}\right)$

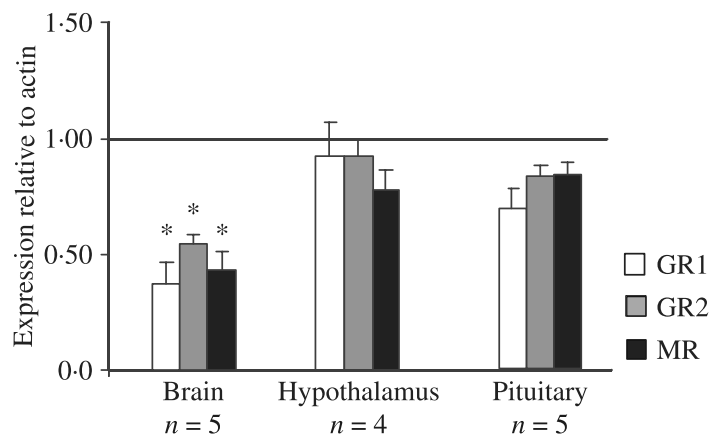

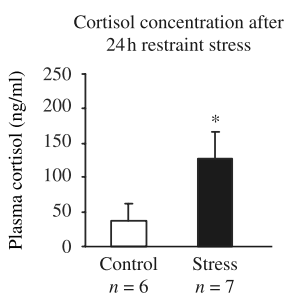

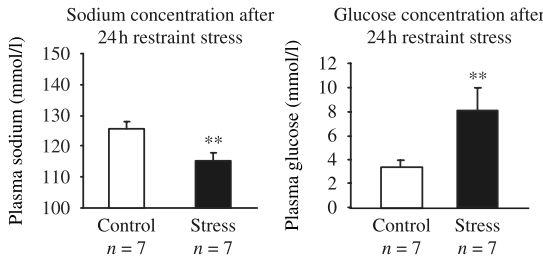

Cortisol concentration after
cold transfer stress $\left(23-10^{\circ} \mathrm{C}\right)$
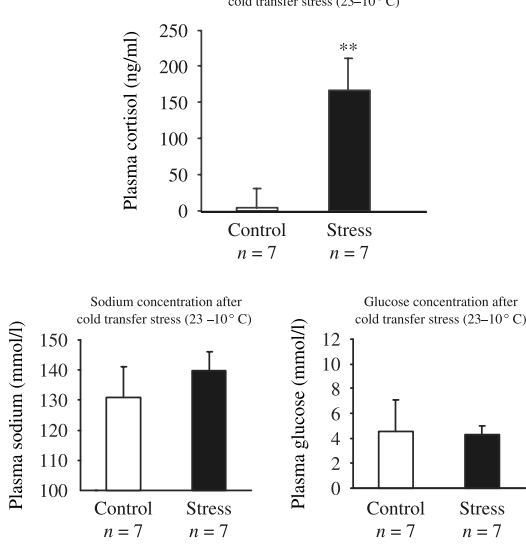

Figure 7 Corticosteroid receptor expression in stress exposed fish. Gene expression of corticosteroid receptors in stress axis organs after 24 -h restraint stress (A) and cold transfer $\left(23^{\circ} \mathrm{C}\right.$ to $\left.10^{\circ} \mathrm{C}\right)$ stress (B). Inserts of plasma cortisol, glucose and sodium levels are shown for control and stressed animals for the respective experiments. Gene expression is shown in comparison with unstressed control fish of the respective experiment and relative to $\beta$-actin.

duplication in the tetrapod lineage. The duplication in all likelihood results from an early genome duplication 300-450 million years ago, and only after the divergence of the tetrapods from the fish lineage (Volff 2005). If we proceed from a notion of a major genomic duplication in fishes, it follows that one MR has apparently been lost during evolution as we were not able to detect a second MR-coding gene in carp or in genomic databases for zebrafish (Danio rerio), puffers (Fugu species) or rice fish (Oryzias latipes). Three possibilities arise after gene/genome duplication: non-functionalisation, the fate of most duplicated genes (Brunet et al. 2006); neo-functionalisation, the acquirement of a new function; or sub-functionalisation, where each copy loses part of the ancestral function and both copies are required to maintain the full function (Force et al. 1999). The duplicated GR genes of fish escaped a fate as non-functional pseudogene: expression levels and differential sensitivities for cortisol are more, so in-line with neo- or sub-functionalisation (Bury et al. 2003, Greenwood et al. 2003). Interestingly, zebrafish has only one GR copy that clusters with other fish GR2 sequences. However, zebrafish has acquired a splicing $\beta$-isoform of the GR (Fig. 2) that resembles the dominant negative GR $\beta$ of humans in structure, expression level and function. This could reflect an alternative regulatory mechanism to compensate for the loss of a functional second GR gene (Schaaf et al. 2008).

Receptor functional definition by transactivation capacity In carp, transactivation capacity of cortisol (capacity of hormone to initiate or repress CR-mediated transcription of downstream genes) is about three-fold higher for GR2 $\left(\mathrm{EC}_{50} 2 \cdot 4 \pm 0 \cdot 4 \mathrm{nM}\right)$ than for GR1 $\left(\mathrm{EC}_{50} 7 \cdot 1 \pm 2 \cdot 9\right)$, and this would facilitate differential regulation by basal and elevated cortisol levels. The carp MR sensitivity $\left(\mathrm{EC}_{50} 4 \cdot 1 \pm 2 \cdot 0 \mathrm{nM}\right)$ is intermediate to that of the GRs, and this is in stark contrast to data for Burton's mouthbrooder and trout, with MRs more sensitive to cortisol than the GRs (Greenwood et al. 2003, Sturm et al. 2005). In fish, levels of up to $10 \mathrm{nM}$ DOC were published (Campbell et al. 1980). The low $\mathrm{EC}_{50}$ of DOC $(0 \cdot 25 \mathrm{nM})$ for MR transactivation in carp certainly does not 
exclude a mineralocorticoid function for DOC in fishes. In carp plasma basal, total levels of cortisol are around $5 \mathrm{ng} / \mathrm{ml}$ (i.e. $13.8 \mathrm{nM}$ ); following stress, cortisol levels easily reach $150 \mathrm{ng} / \mathrm{ml}(>400 \mathrm{nM})$. As only $20 \%$ is available as unbound cortisol (Flik \& Perry 1989), this corresponds to $2 \cdot 8$ and $>$ $80 \mathrm{nM}$ respectively, for which in carp apparently specific receptor subtypes are present: at rest both GR2 and MR may be occupied and activated, whereas GR1 is preferentially activated by stress levels of cortisol. In rodent brain, a similar system was demonstrated: an 80\% MR and 10\% GR corticosterone occupancy was established in non-stressed situations (Reul et al. 1987). Even though the majority of MRs is occupied at low cortisol levels, it still is a dynamically regulated receptor. MR activity could be increased by an agonist to further inhibit HPA axis activity (Buckley et al. 2007). We assume the same applies for common carp GR2 and MR. This means that although both receptors are partly or even largely occupied with cortisol, continuous modulation of HPI axis activity could be mediated by increasing cortisol levels after stressful events via GR1.

Receptor functional definition by localisation As we focus on the involvement of the different receptors in stress axis regulation, our areas of interest are the HPI axis organs. Hypothalamus and pituitary gland of unstressed carp showed comparable mRNA levels for both the GRs and MR, suggesting functional importance of all the three. Only in the brain (without hypothalamus and pituitary gland), a consistent twofold higher mRNA expression for GR1 over GR2 was seen. A receptor-defined duality in GR function in the brain of fishes seems of wider occurrence as similar preferential expression was seen in the brain of rainbow trout and Burtons' mouthbrooder (Bury et al. 2003, Greenwood et al. 2003). The higher mRNA expression level could translate into higher protein levels but may also reflect higher turnover. We have no data on brain cortisol levels but two receptors with significant difference in receptor sensitivity would allow differential responses to basal and stress levels of the steroid. In carp and trout (Sturm et al. 2005), the brain shows strong MR mRNA expression; unexpectedly, typical osmoregulatory organs such as gills, kidney and intestine show far lower MR mRNA expression. This suggests that a widely accepted but only presumed hypothesis of MR involvement in osmoregulation may be wrong, and is a consequence of extrapolation of the situation for aldosterone and MR function in mammals. However, also in the mammalian brain, MRs play a key role in corticosteroid-regulated processes (De Kloet et al. 1998). The mammalian hippocampus exerts inhibitory control over the HPA axis activity: a dominant inhibition by MR activity is attenuated by GR activation (De Kloet $e t$ al. 1998). Our results support such a combined function for steroids mediated by GR and MR activities in the regulation of stress coping and learning, and this is apparently a very early function developed in our ancestral fishes.

Steroid receptors distribution in telencephalic regions may contribute to define hippocampal regions, especially involved in (learning) behaviour and sentience. Our demonstration of GR and MR mRNA in carp telencephalon expands and further substantiates the notion that GR and MR corticosteroid receptors have the basic functions in the regulation of learning and memory. In goldfish (Vargas et al. 2006) and cod (Nilsson et al. 2008) learning and spatial memory may involve the telencephalic lateral pallium, the homologue of the hippocampus of mammals (Meek \& Nieuwenhuys 1998).

In the hypothalamus, mRNA of all the three receptor genes is expressed in parvo- and magnocellular neurons of the pre-optic nucleus. We confirmed (data not shown) by immunohistochemistry on adjacent sections that expression of GR- and MR-mRNA co-localises with CRH (Huising et al. 2004). So far, the presence of GR protein in these cells was shown for rainbow trout (Teitsma et al. 1998) and Mozambique tilapia (Oreochromis mossambicus) (Pepels et al. 2004). However, the antiserum used in these studies does not distinguish between GR gene species. To the best of our knowledge, no data on MR distribution in other fish brains are available. In mammals, the MR was described in the ventromedian and arcuate nuclei of the hypothalamus, and the GR in the arcuate nuclei, paraventricular and supra-optic nucleus of the hypothalamus (Reul \& de Kloet 1985); the hypothalamic arcuate nucleus is an important target for metabolic and hormonal signals controlling food intake and feeding behaviour (Meister 2007). Clearly, future studies on GR and MR localisation in the fish analogues of these structures are warranted as we know that regulation of stress on feeding (arcuate nucleus in fish) are strongly intertwined, also in fish (Bernier et al. 2004).

In carp pituitary gland, the two GR genes co-localise in the same areas. Remarkably, little expression was seen in pars intermedia and would imply limited feedback by cortisol on MSH- and somatolactin-producing cells. This reminds of the situation reported for trout (Teitsma et al. 1998), but not for tilapia that has significant GR-immunoreactivity in the pars intermedia (Pepels et al. 2004), although mRNA expression could not be detected (Kitahashi et al. 2007). The strongest signal for GR mRNA was seen in the proximal pars distalis GH cells (in line with observations for GR1 on trout (Teitsma et al. 1998) and tilapia (Pepels et al. 2004, Kitahashi et al. 2007)). Stress/cortisol induced suppression of growth, for instance seen after handling or confinement offishes is thus explained by down-regulation of GH cells (Auperin et al. 1997). In the rostral pars distalis finally, ACTH cells express significant levels of GR mRNA, as one could predict as a basis for feedback control in the stress axis. Interestingly, recent data in tilapia showed no mRNA expression of either of the duplicated GRs in ACTH-producing cells (Kitahashi et al. 2007), whereas immuno-histochemical studies with an antibody against GR showed positivity in ACTH cells in tilapia and rainbow trout (Teitsma et al. 1998, Pepels et al. 2004). Prolactin cells, however, known to become activated during chronic stress (Auperin et al. 1997), showed no detectable GR expression (Teitsma et al. 1998). This only seems at variance with recent reports on direct effects of cortisol on prolactin cells (Uchida et al. 2004): a G-protein-coupled membrane receptor for cortisol should be considered. Indeed, the reported effects of 
cortisol on prolactin cells reported are fast, faster than one would predict for GR/MR-mediated genomic effects.

MR mRNA was far more abundant in the pars distalis than in the pars intermedia. Based on the comparisons with GR staining, we predict the MR expression to be scarcely expressed in the $\alpha$-MSH cells of the pars intermedia and strongly expressed in the GH cells of the pars distalis. Unfortunately, we were unable to demonstrate MR mRNA in ACTH cells specifically. Assuming (by analogy to the situation for GR mRNA) absence of MR mRNA in prolactin cells, our RQ-PCR data would favour the presence of MR in ACTH cells; this part of our study requires future attention.

\section{Physiology}

Restraint by netting for $24 \mathrm{~h}$ resulted in hyperglycaemia, hyponatraemia, typical signs of strong catecholaminergic activation and inherent loss of control over integumental permeability to water and ions (Wendelaar Bonga 1997). A persistent hypercortisolinaemia was observed, but the duration of the stress condition proved insufficient to induce feedback by cortisol. However, a more persistent stress of repeated cold transfer induced high cortisol levels and hyperglycaemia and mild hypernatraemia indicative of adoption to the stressor. Mild hypernatraemia is typical for enhanced prolactin activity and successful restoration of blood mineral levels to a new set point (Metz et al. 2003). This longer term adaptation process did involve measurable downregulation of CRs in the brain (without hypothalamus and pituitary gland). This observation suggests a central initiation of down-regulation of cortisol release, rather than direct feedback via NPO or pituitary gland. In tilapia, a similar regulation system was suggested; cortisol feedback on $\mathrm{CRH}$ release is exerted via the forebrain medial part of dorsal telencephalon (Pepels et al. 2004). Our observation of GR and MR mRNA down-regulation only following the persistent stress is further consistent with experiments on Coho salmon (Oncorhynchus kisutch) that showed no effect of acute stress on GR expression, whereas chronically elevated cortisol levels in several other paradigms did (Maule \& Schreck 1991).

The MR mRNA in carp brain was down-regulated to the same extent as the mRNA levels of both GRs. This seems in contrast with the mammalian model where GR stimulates HPA axis activity, whereas MR has an inhibiting effect (De Kloet et al. 1998). However, a similar result was found in hippocampus of rats exposed to increasing the corticosteroid levels (Hugin-Flores et al. 2004). And in mouse pups with high corticosteroid levels due to 24-h maternal deprivation, both GR and MR mRNA expression were significantly decreased (Schmidt et al. 2003). These discrepancies between different stressors are thus of wider occurrence and require further and species specific approaches.

In conclusion, we show that carp express separate GRs for regulation under basal and stressful conditions. We predict an ancestral role not only for the duplicated GRs but also for
MR in stress physiology, based on the receptor localisation and expression profile after chronic stress and provide a receptor profile in the brain conform memory and learning functionalities in fishes as in higher vertebrates. A role for DOC in stress physiology in fishes has never been considered but seems a reasonable hypothesis for future research. More in-depth studies on specific roles of these receptors in learning and stress physiology would therefore elucidate early strategies in vertebrate evolution to control the basics of life.

\section{Declaration of Interest}

The authors declare that there is no conflict of interest that would prejudice the impartiality of this scientific work.

\section{Funding}

Support of the Smart Mix Programme of the Netherlands Ministry of Economic Affairs and the Netherlands Ministry of Education, Culture and Science is gratefully acknowledged.

\section{Acknowledgements}

We gratefully acknowledge Ms Sandra Janssen and Mrs Liesbeth Pierson for their excellent technical assistance during the experiments. F A Tom Spanings is thanked for excellent fish husbandry.

\section{References}

Altschul SF, Madden TL, Schaffer AA, Zhang J, Zhang Z, Miller W \& Lipman DJ 1997 Gapped BLAST and PSI-BLAST: a new generation of protein database search programs. Nucleic Acids Research 25 3389-3402.

Arends RJ, van der Gaag R, Martens GJ, Wendelaar Bonga SE \& Flik G 1998 Differential expression of two pro-opiomelanocortin mRNAs during temperature stress in common carp (Cyprinus carpio L.). Journal of Endocrinology 159 85-91.

Auperin B, Baroiller JF, Ricordel MJ, Fostier A \& Prunet P 1997 Effect of confinement stress on circulating levels of growth hormone and two prolactins in freshwater-adapted tilapia (Oreochromis niloticus). General and Comparative Endocrinology 108 35-44.

Baker ME, Chandsawangbhuwana C \& Ollikainen N 2007 Structural analysis of the evolution of steroid specificity in the mineralocorticoid and glucocorticoid receptors. BMC Evolutionary Biology 724.

Balment RJ \& Henderson IW 1987 In Secretion of Endocrine Glands and Their Relationship to Osmoregulation, Eds I Chester-Jones, PM Ingleton \& JG Phillips. New York: Plenum press.

Basu N, Kennedy CJ \& Iwama GK 2003 The effects of stress on the association between hsp70 and the glucocorticoid receptor in rainbow trout. Comparative Biochemistry and Physiology. Part A, Molecular and Integrative Physiology 134 655-663.

Bernier NJ, Bedard N \& Peter RE 2004 Effects of cortisol on food intake, growth, and forebrain neuropeptide $\mathrm{Y}$ and corticotropin-releasing factor gene expression in goldfish. General and Comparative Endocrinology 135 230-240.

Bridgham JT, Carroll SM \& Thornton JW 2006 Evolution of hormonereceptor complexity by molecular exploitation. Science 312 97-101.

Brunet FG, Crollius HR, Paris M, Aury JM, Gibert P, Jaillon O, Laudet V \& Robinson-Rechavi M 2006 Gene loss and evolutionary rates following whole-genome duplication in teleost fishes. Molecular Biology and Evolution 23 1808-1816. 
Buckley TM, Mullen BC \& Schatzberg AF 2007 The acute effects of a mineralocorticoid receptor (MR) agonist on nocturnal hypothalamicadrenal-pituitary (HPA) axis activity in healthy controls. Psychoneuroendocrinology 32 859-864.

Bury NR \& Sturm A 2007 Evolution of the corticosteroid receptor signalling pathway in fish. General and Comparative Endocrinology 153 47-56.

Bury NR, Sturm A, Le Rouzic P, Lethimonier C, Ducouret B, Guiguen Y, Robinson-Rechavi M, Laudet V, Rafestin-Oblin ME \& Prunet P 2003 Evidence for two distinct functional glucocorticoid receptors in teleost fish. Journal of Molecular Endocrinology 31 141-156.

Campbell CM, Fostier A, Jalabert B \& Truscott B 1980 Identification and quantification of steroids in the serum of rainbow trout during spermiation and oocyte maturation. Journal of Endocrinology 85 371-378.

Chenna R, Sugawara H, Koike T, Lopez R, Gibson TJ, Higgins DG \& Thompson JD 2003 Multiple sequence alignment with the Clustal series of programs. Nucleic Acids Research 31 3497-3500.

Engelsma MY, Stet RJ, Schipper H \& Verburg-van Kemenade BM 2001 Regulation of interleukin 1 beta RNA expression in the common carp, Cyprinus carpio L. Developmental and Comparative Immunology 25 195-203.

Flik G \& Perry SF 1989 Cortisol stimulates whole body calcium uptake and the branchial calcium pump in freshwater rainbow trout. Journal of Endocrinology 120 75-82.

Force A, Lynch M, Pickett FB, Amores A, Yan YL \& Postlethwait J 1999 Preservation of duplicate genes by complementary, degenerative mutations. Genetics 151 1531-1545.

Gilmour KM 2005 Mineralocorticoid receptors and hormones: fishing for answers. Endocrinology 146 44-46.

Greenwood AK, Butler PC, White RB, DeMarco U, Pearce D \& Fernald RD 2003 Multiple corticosteroid receptors in a teleost fish: distinct sequences, expression patterns, and transcriptional activities. Endocrinology 144 4226-4236.

Huang X \& Miller W 1991 A time-efficient, linear-space local similarity algorithm. Advances in Applied Mathematics 12 337-357.

Hugin-Flores ME, Steimer T, Aubert ML \& Schulz P 2004 Mineralo- and glucocorticoid receptor mrnas are differently regulated by corticosterone in the rat hippocampus and anterior pituitary. Neuroendocrinology 79 174-184.

Huising MO, Metz JR, van Schooten C, Taverne-Thiele AJ, Hermsen T, Verburg-van Kemenade BM \& Flik G 2004 Structural characterisation of a cyprinid (Cyprinus carpio L.) CRH, CRH-BP and CRH-R1, and the role of these proteins in the acute stress response. Journal of Molecular Endocrinology 32 627-648.

Irnazarow I 1995 Genetic variability of Polish and Hungarian carp lines. Aquaculture 129 215-219.

Kitahashi T, Ogawa S, Soga T, Sakuma Y \& Parhar I 2007 Sexual maturation modulates expression of nuclear receptor types in laser-captured single cells of the cichlid (Oreochromis niloticus) pituitary. Endocrinology 148 5822-5830.

De Kloet ER, Vreugdenhil E, Oitzl MS \& Joels M 1998 Brain corticosteroid receptor balance in health and disease. Endocrine Reviews 19 269-301.

Kumar S, Tamura K \& Nei M 2004 MEGA3: integrated software for molecular evolutionary genetics analysis and sequence alignment. Briefings in Bioinformatics 5 150-163.

Maule AG \& Schreck CB 1991 Stress and cortisol treatment changed affinity and number of glucocorticoid receptors in leukocytes and gill of coho salmon. General and Comparative Endocrinology 84 83-93.

Meek J \& Nieuwenhuys R 1998 In The Central Nervous System of Vertebrates 2: Holosteans and Teleosts, Eds R Nieuwenhuys, HJ Ten Donkelaar \& C Nicholson. Heidelberg: Springer-Verlag.

Meister B 2007 Neurotransmitters in key neurons of the hypothalamus that regulate feeding behavior and body weight. Physiology and Behavior 92 263-271.

Metz JR, van den Burg EH, Bonga SE \& Flik G 2003 Regulation of branchial $\mathrm{Na}(+) / \mathrm{K}(+)$-ATPase in common carp Cyprinus carpio L. acclimated to different temperatures. Journal of Experimental Biology 206 2273-2280.

Mommsen TP, Vijayan MM \& Moon TW 1999 Cortisol in teleosts: dynamics, mechanisms of action, and metabolic regulation. Reviews in Fish Biology and Fisheries 9 211-268.
Nei M \& Kumar S 2000 Molecular Evolution and Phylogenetics, New York: Oxford University Press Inc.

Nilsson J, Kristiansen TS, Fosseidengen JE, Ferno A \& van den Bos R 2008 Learning in cod (Gadus morhua): long trace interval retention. Animal Cognition 11 215-222.

Pepels PP, Van Helvoort H, Wendelaar Bonga SE \& Balm PH 2004 Corticotropin-releasing hormone in the teleost stress response: rapid appearance of the peptide in plasma of tilapia (Oreochromis mossambicus). Journal of Endocrinology 180 425-438.

Pfaffl MW 2001 A new mathematical model for relative quantification in realtime RT-PCR. Nucleic Acids Research 29 e45.

Prunet P, Sturm A \& Milla S 2006 Multiple corticosteroid receptors in fish: from old ideas to new concepts. General and Comparative Endocrinology 147 $17-23$.

Reul JM \& de Kloet ER 1985 Two receptor systems for corticosterone in rat brain: microdistribution and differential occupation. Endocrinology 117 2505-2511.

Reul JM, van den Bosch FR \& de Kloet ER 1987 Relative occupation of type-I and type-II corticosteroid receptors in rat brain following stress and dexamethasone treatment: functional implications. Journal of Endocrinology 115 459-467.

Reul JM, Gesing A, Droste S, Stec IS, Weber A, Bachmann C, Bilang-Bleuel A, Holsboer F \& Linthorst AC 2000 The brain mineralocorticoid receptor: greedy for ligand, mysterious in function. European Journal of Pharmacology $405235-249$.

Sambrook J \& Russell DW 2001 Molecular Cloning, New York: Cold Spring Harbor Laboratory Press.

Schaaf MJ, Champagne D, van Laanen IH, van Wijk DC, Meijer AH, Meijer OC, Spaink HP \& Richardson MK 2008 Discovery of a functional glucocorticoid receptor $\beta$-isoform in zebrafish. Endocrinology 149 1591-1599.

Schmidt MV, Oitzl MS, Muller MB, Ohl F, Wurst W, Holsboer F, Levine S \& De Kloet ER 2003 Regulation of the developing hypothalamic-pituitaryadrenal axis in corticotropin releasing hormone receptor 1-deficient mice. Neuroscience 119 589-595.

Stolte EH, van Kemenade BM, Savelkoul HF \& Flik G 2006 Evolution of glucocorticoid receptors with different glucocorticoid sensitivity. Journal of Endocrinology 190 17-28.

Sturm A, Bury N, Dengreville L, Fagart J, Flouriot G, Rafestin-Oblin ME \& Prunet $\mathrm{P} 2005$ 11-deoxycorticosterone is a potent agonist of the rainbow trout (Oncorhynchus mykiss) mineralocorticoid receptor. Endocrinology 146 47-55.

Teitsma CA, Anglade I, Toutirais G, Munoz-Cueto JA, Saligaut D, Ducouret B \& Kah O 1998 Immunohistochemical localization of glucocorticoid receptors in the forebrain of the rainbow trout (Oncorhynchus mykiss). Journal of Comparative Neurology 401 395-410.

Uchida K, Yoshikawa-Ebesu JS, Kajimura S, Yada T, Hirano T \& Gordon Grau E 2004 In vitro effects of cortisol on the release and gene expression of prolactin and growth hormone in the tilapia, Oreochromis mossambicus. General and Comparative Endocrinology 135 116-125.

Vargas JP, Bingman VP, Portavella M \& Lopez JC 2006 Telencephalon and geometric space in goldfish. European Journal of Neuroscience 24 2870-2878.

Volff JN 2005 Genome evolution and biodiversity in teleost fish. Heredity 94 280-294.

Wendelaar Bonga SE 1997 The stress response in fish. Physiological Reviews 77 591-625.

Received in final form 25 April 2008

Accepted 27 May 2008

Made available online as an Accepted Preprint 27 May 2008 